\title{
The Effect of Ultrasonic Pre-Treatment on the Temperature Controlled Infrared Drying of Loligo vulgaris and Comparison with the Microwave Drying
}

\author{
Zehra Ozden Ozyalcin ${ }^{1}$, Azmi Seyhun Kipcak ${ }^{1, *}$ (B)
}

${ }^{1}$ Yildiz Technical University, Faculty of Chemical and Metallurgical Engineering, Department of Chemical Engineering, Istanbul, Turkey.

\section{Article History}

Received 11 September 2020

Accepted 26 December 2020

First Online 29 December 2020

\section{Corresponding Author}

Tel.: +902123834784

E-mail: skipcak@yildiz.edu.tr

\section{Keywords}

Activation energy

Effective moisture diffusivity

Squid

Ultrasonic pre-treatment

\begin{abstract}
In this study the effect of ultrasonic pre-treatment (US) on the thin-layer infrared (IR) drying kinetics and modelling of Loligo vulgaris (Squid) were studied and obtained data were compared with the microwave drying (MW). In each three methods, effective moisture diffusivities $\left(D_{\text {eff }}\right)$ and activation energies $\left(E_{a}\right)$ were determined. According to the drying curves of Loligo vulgaris the highest drying times were found in IR and the lowest drying times were found in MW methods. Therefore, ultrasonic pre-treatment decreased the drying times. Drying takes place in the falling-rate period generally. Midilli \& Kucuk model best fit the experimental data for each method with the coefficient of determination $\left(\mathrm{R}^{2}\right)$ values higher than 0.995 . Highest $D_{\text {eff }}$ values were found in MW method and calculated between $1.25 \times 10^{-8}-5.62 \times 10^{-8} \mathrm{~m}^{2} / \mathrm{s}$, and the lowest $D_{\text {eff }}$ values were found in IR method and calculated between $6.57 \times 10^{-10}-1.35$ $\times 10^{-9} \mathrm{~m}^{2} / \mathrm{s}$. Moreover, $E_{a}$ values were found 35.20 and $37.12 \mathrm{~kJ} / \mathrm{mol}$ for IR and US-IR, and 35.43 for MW methods. Drying time, temperature and power levels lead to color changes.
\end{abstract}

\section{Introduction}

Seafoods have been used for many years with their high protein content and wide range of consumability. One of the most important marine species is Loligo vulgaris considering its commercial value in the southern European coast and in the Mediterranean region. Loligo vulgaris or the European squid is a wellknown large squid belonging to the family Loliginidae. Squid has a large habitat along the eastern Atlantic Ocean and especially in the Mediterranean. Thus, it has been a target of the researches for many years and is one of the best known European cephalopod species (Jereb et al., 2015, Abdelmalek et al., 2016). FAO reports the estimated annual global production of Loligo vulgaris is more than 293,000 tonnes. Countries that are known with a highest level of production are Croatia, Cyprus, Malta and Germany, respectively (FAO, 2017).
Food products tend to deteriorate under normal conditions due to their microbiological activities. Since the activity of microorganisms stops in a limited humidity environment, drying is the most effective method of preservation. For the past two decades, microwave and infrared drying have been remarkable methods in dehydration of various products (Doymaz et al., 2015a, b; Kipcak, 2017). Microwave drying has superior thermal efficiency and rapid drying rate throughout the response time, so it is a unique method for saving time and energy. Infrared drying also saves energy compared to traditional drying methods as it heats the material rapidly and uniformly without heating the surrounding air. Besides that, infrared drying gives a better-quality product with its uniform temperature distribution (Adak et al. 2016).

In recent years, with the increase in dry food consumption, the tradition of drying food products has 
started to differ from the old times. Although there have been many meat studies in the literature, seafood related studies did not reach sufficient numbers. Examples of drying studies with different meat products can be given as; Mewa (2019) studied solar tunnel drying of beef, Ahmat et al. (2015) studied convective drying of beef, and Sa-Adchom et al. (2011) studied superheated steam drying of pork. For the drying of chicken, Osman (2017) studied with convective dryer, Hii et al. (2014) studied convection oven drying raw and cooked chicken, and Ayanwale et al. (2007) studied sun and oven drying of the meat and chicken pieces. Compared to other meat product, sea products are studied extremely rare in drying studies. Examples include the following studies as; Namsanguan (2004) studied two-stage drying processes of shrimp, VegaGálvez et al. (2011) studied osmo-treated jumbo squid drying and Kipcak et al. (2017 \& 2019) studied the microwave and infrared drying of mussel. For fish drying studies, Mohd Rozainee and Ng (2010) studied the microwave-convective hot air drying, and Purnomo Sidh (2018) studied greenhouse drying of salted fish.

Ultrasounds can be defined as the vibrations of a frequency from $20 \mathrm{kHz}$ to $100 \mathrm{MH}$. The mechanical energy provided to the gas-solid or liquid-solid systems via ultrasonic waves to reduce internal and external mass transfer resistance (Nowacka et al. 2012). When the forces involved in the mechanism is higher than the surface tension of the water molecules within the capillaries of the material, microscopic channels are created and facilitate to exchange of matter (so called "sponge effect") (Liu et al. 2018). These capillaries are useful for reducing the resistance of internal moisture migrating to the surface and increasing the drying rate effectively (Liu et al. 2018). In general, as the porosity increases, the material softness increases, and the mechanical compression and expansion produced by ultrasound becomes easier.

The ultrasonic pre-treatment reduces the process time of the drying processes. Thus, it saves a lot of energy, especially in expensive and long-term processes (Nowacka et al., 2012; Fernandes et al., 2019). For various food products, ultrasound has been using during the drying to enhance the process. In this field, many studies have been carried out mainly about the drying of the vegetables and fruits in the literature. As examples of drying studies with ultrasound pre-treatment; Fernandes et al. (2008) studied effects on melon cell structure, Romero \& Yépez v. (2014) studied convective drying of Andean blackberry. The osmotic dehydration of strawberries is studied by Garcia-Noguera et al. (2010), Nowacka et al. (2012) apple cubes drying, Fernandes et al. (2019) convective air-drying of mangoes, and La Fuente \& Tadini (2017) studied on unripe bananas to produced flour by air-drying. Drying studies on other products than vegetables and fruits are very rare. Exemplarily; vacuum drying of honey enhanced with ultrasound studied by Liu et al. (2018). Başlar et al. (2014) studied ultrasonic vacuum drying of chicken meat and beef, Zhengbin (2014) studied vacuum drying of wood and Duan (2008) studied microwave freeze drying of sea cucumber.

It is seen from the literature despite the studies about the drying of food products, there are only a few studies about the drying characteristics of sea products. In this respect, the infrared drying of Loligo vulgaris was studied at the drying temperatures of 60,70 and $80^{\circ} \mathrm{C}$. After than ultrasonic pre-treatment was applied in order to find the effect of ultrasound on the drying curves and kinetics. Moreover, the results of infrared drying were compared with the microwave drying results and mathematical modelling of all methods was studied.

\section{Materials and Methods}

\section{Samples and Equipments}

Loligo vulgaris, which are produced by Kerevitaş (Kerevitaş Industry and Commerce Inc., Bursa, Turkey) was bought from the local market in Turkey in February 2019 and were kept in a refrigerator (1050T model; Arcelik, Eskisehir, Turkey) at a temperature of $-18^{\circ} \mathrm{C}$. Before the experiments Loligo vulgaris was taken from the refrigerator and waited in a desiccator to reach the temperature equilibrium. There parallel samples of Loligo vulgaris were weighted as $10.0 \pm 0.2 \mathrm{~g}$ for the determination of moisture content and were cut as thin layer of a thickness of $0.6 \mathrm{~cm}$. The average moisture content was determined by using a MA 50.R model infrared moisture analyzer (Radwag Balances and Scales, Radom, Poland) at $120{ }^{\circ} \mathrm{C}$ and found to be $79.49 \%$ on wet basis, which corresponds to $3.87 \mathrm{~kg}$ water/kg dry matter on a dry basis.

Infrared drying experiments were fulfilled using the same MA 50.R model infrared moisture analyzer which works with $230 \mathrm{~V}$ at $50 \mathrm{MHz}$ (Radwag Balances and Scales, Radom, Poland). The pre-treatment process was performed with using an Ultrasonic bath which has an accuracy of $1^{\circ} \mathrm{C}$ and $120 \mathrm{~W}$ ultrasonic power (Isolab, Germany). For the microwave drying process a home type Delonghi MW205S model microwave dryer with a working the interval of 140-790W (Delonghi, Treviso, Italy) was used.

\section{Experimental Method}

Like in the determination of moisture content the samples were prepared for the drying experiments. In the first method infrared radiation (IR) dryer was used. The drying temperatures were selected as 60, 70 and $80^{\circ} \mathrm{C}$ like most of the drying studies in literature (Doymaz, 2010; Doymaz \& Özdemir, 2014). The samples' weight was noted from infrared radiation dryer screen at the intervals of 15 minutes for each temperature level. In the second method, ultrasound pre-treatment process before infrared radiation (US-IR) was applied at $30^{\circ} \mathrm{C}$ and 10 minutes like in the study done by Rodrigues \& Fernandes (2007). After ultrasound pre-treatment 
due to the swelling of samples, the average moisture content was again determined by using the infrared moisture analyzer at $120{ }^{\circ} \mathrm{C}$ and found to be $87.8 \%$ on wet basis, which corresponds to $7.2 \mathrm{~kg}$ water $/ \mathrm{kg}$ dry matter on a dry basis. Then the samples were dried with infrared radiation dryer with the same temperatures of 60,70 and $80^{\circ} \mathrm{C}$. In the third method microwave radiation (MW) was used at 140, 210 and $350 \mathrm{~W}$ power. The samples' weight was recorded for $140 \mathrm{~W}$ at intervals of 30 seconds and for 210 and $350 \mathrm{~W}$ at intervals of 1 minute as given in the study of Kipcak \& İsmail, 2020. Drying was proceed until the moisture in the product decreased to $5 \%$. The samples were cooled at room temperature when the drying was finished. Afterwards, dried samples, which are given in Figure 1, were packed into polyethylene bags and to keep in safe from moisture they were placed in a desiccator.

\section{Modelling and Regression Analyses}

The moisture content (M), drying rate (DR) and moisture ratio $(M R)$, were calculated during drying experiments are presented by the equations given in (1), (2) and (3) (Kipcak, 2017; Kipcak \& İsmail, 2018; Kipcak et al., 2019; Sevim et al., 2019):

$$
M=\frac{m_{w}}{m_{d}}
$$

where $\mathrm{M}$ is the moisture content ( $\mathrm{kg}$ water/ $\mathrm{kg}$ dry matter), $m_{w}$ is the water content $(\mathrm{kg}), m_{d}$ is the dry matter content $(\mathrm{kg})$.

$$
D R=\frac{M_{t+d t}-M_{t}}{d t}
$$

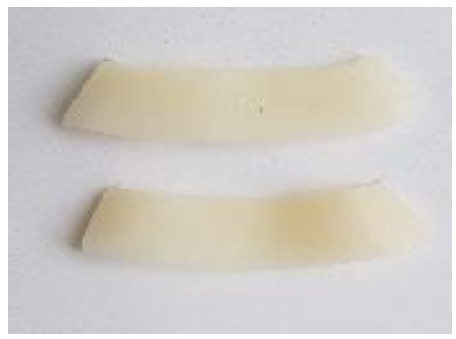

Fresh

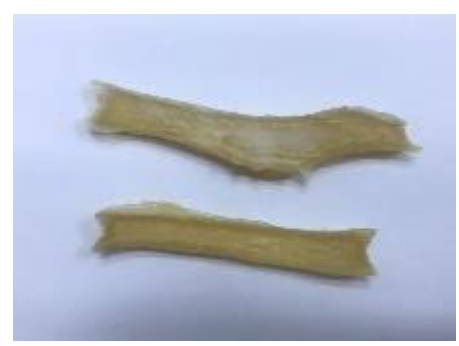

IR 60

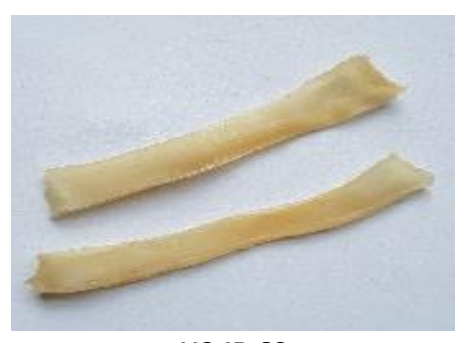

US-IR 60

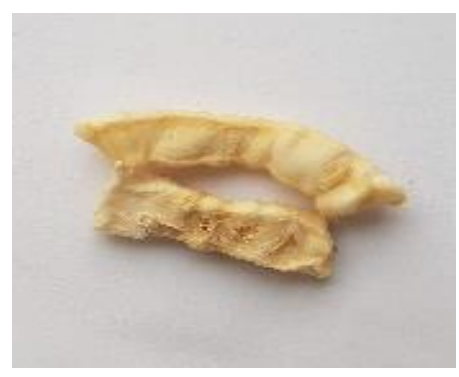

MW 140

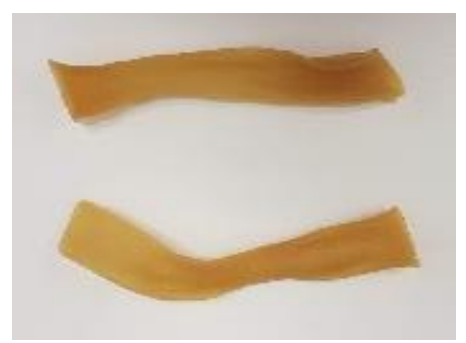

IR 70

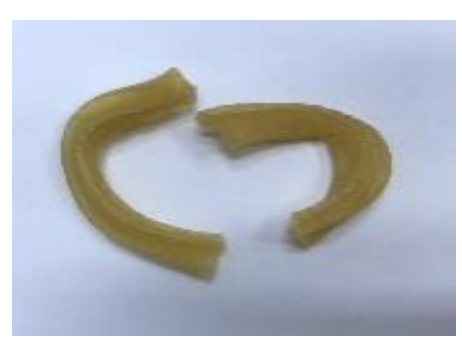

US-IR 70

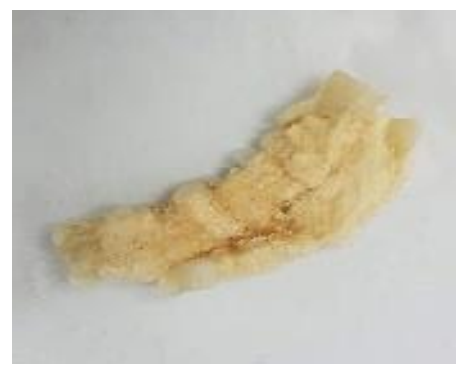

MW 210

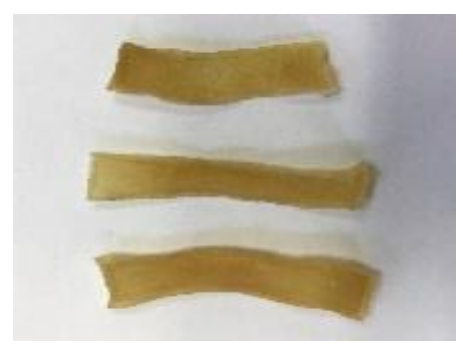

IR 80

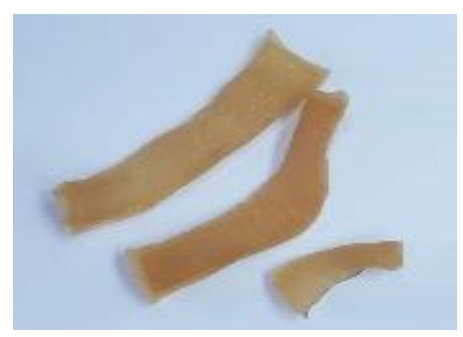

US-IR 80

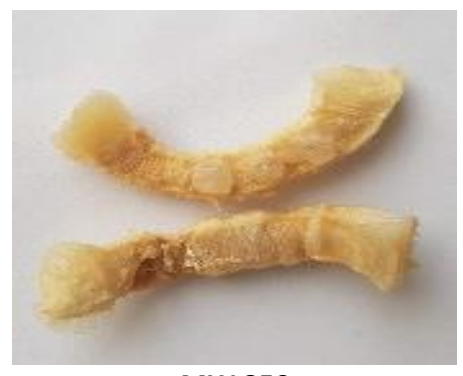

MW 350

Figure 1. Pictures of fresh and dried Loligo vulgaris dried by: IR, US-IR and MW. 
where DR is the drying rate $(\mathrm{kg}$ water $/ \mathrm{kg}$ dry matter $\mathrm{x} \min ), \mathrm{M}_{\mathrm{t}+\mathrm{dt}}$ is the moisture content at $t+d t(\mathrm{~kg}$ water/kg dry matter), $t$ is the drying time (min).

$$
M R=\frac{M_{t}-M_{e}}{M_{i}-M_{e}}
$$

where $\mathrm{MR}$ is the moisture ratio (dimensionless), $M_{t}, M_{0}$, and $M_{e}$ relate to the moisture content at any drying time, initial moisture content and equilibrium moisture content (kg water/kg dry matter), respectively. In the calculations, $M_{e}$ is generally neglected due to its small amount.

The drying curve data of each method of IR, US-IR and $\mathrm{MW}$ were fitted to 14 most widely used mathematical models of Aghbaslo et al., Alibas, Henderson et al., Jena \& Das, Lewis, Logarithmic, Midilli \& Kucuk, Page, Parabolic, Peleg, Two-term exp., Verma et al., Wang et al. and Weibull (4-17).

Parameters of models were predicted using a nonlinear regression procedure based on the LavenbergMarquardt algorithm applied by Statistica 8.0 (StatSoft Inc., Tulsa, USA). To determine the best fitted model, coefficient of determination $\left(R^{2}\right)$, reduced chi-square $\left(\chi^{2}\right)$ and root mean square error (RMSE) statistical evaluation methods were applied and equation are given in (4), (5) and (6), respectively. Higher $R^{2}$ values and lower $\chi^{2}$ and RMSE values were accepted as better results in the literature (Doymaz et al., 2015a,b).

$$
\begin{aligned}
R^{2} \equiv 1-\frac{\sum_{i=1}^{N}\left(M R_{\text {exp }, i}-M R_{\text {pre }, i}\right)^{2}}{\sum_{i=1}^{N}\left(M R_{\text {exp }, i}-\left(\frac{1}{n}\right) \sum_{i=1}^{N} M R_{\text {exp }, i}\right)} \\
\chi^{2}=\frac{\sum_{i=1}^{N}\left(M R_{\text {exp }, i}-M R_{\text {pre }, i}\right)^{2}}{N-z} \\
R M S E=\left(\frac{1}{N} \sum_{i=1}^{N}\left(M R_{\text {prei }}-M R_{\exp , i}\right)^{2}\right)^{1 / 2}
\end{aligned}
$$

where $M R_{\text {exp }}$ and $M R_{\text {pre }}$ represent experimental and predicted values of moisture ratios, respectively. $N$ is the total number of experiments, and $z$ is the number of constants in the model.

\section{Determination of the Effective Moisture Diffusivity}

Drying of food materials is a function of internal diffusion and generally occurs in the falling rate period. Several mathematical models have been proposed using Fick's second law to describe drying processes during falling rate period. The analytical solution of the Fick's second law, with the assumptions of mass transfer (moisture migration) is by diffusion only, diffusion coefficient is constant, and shrinkage is negligible, and temperature is constant during the dehydration drying process in unsteady state thin-layer diffusion can be given as (7) (Doymaz et al., 2015a):

$$
M R=\frac{8}{\pi^{2}} \sum_{n=1}^{\infty} \frac{1}{(2 n+1)^{2}} \exp \left(-\frac{(2 n+1)^{2} \pi^{2} D_{e f f} \times t}{4 L^{2}}\right)
$$

where $D_{\text {eff, }} L$ and $t$ are the effective moisture diffusivity $\left(\mathrm{m}^{2} / \mathrm{s}\right)$, the half-thickness of the samples $(\mathrm{m})$ and drying time $(\mathrm{s})$, respectively. Since the first terms of the equations will not affect the results, these are neglected and equation (8) can be simplified as given in (22):

$$
\ln (M R)=\ln \left(\frac{8}{\pi^{2}}\right)-\left(\pi^{2} \frac{D_{e f f} \times t}{4 L^{2}}\right)
$$

From the slope of the $\ln (M R)$ versus $t, D_{\text {eff }}$ can easily be calculated.

\section{Activation Energy Determination}

The energy of activation was calculated using an Arrhenius type equation as (9):

$$
D_{\text {eff }}=D_{0} \exp \left(-\frac{E_{a}}{R(T+273.15)}\right)
$$

where $D_{0}\left(\mathrm{~m}^{2} / \mathrm{s}\right), E_{a}(\mathrm{~kJ} / \mathrm{mol}), \mathrm{R}(\mathrm{kJ} /(\mathrm{mol} \times \mathrm{K}))$ and $\mathrm{T}$ $\left({ }^{\circ} \mathrm{C}\right)$ are the pre-exponential factor of Arrhenius equation, activation energy, universal gas constant $(8.314 \mathrm{~J} / \mathrm{mol} \times \mathrm{K})$ and temperature, respectively.

On the other hand, the temperature is not a directly evaluated variable for the microwave dehydration.

Hence, regulated form of the Arrhenius equation is used in order to find the activation energy. It depends on the interaction between the MW power level to sample weight and effective diffusivity as shown in (10) (Kipcak, 2017):

$$
D_{\text {eff }}=D_{0} \exp \left(-\frac{E_{a} \times m}{P}\right)
$$

where $P$ is the microwave power $(W), m$ is sample weight $(\mathrm{kg})$ and $E_{\text {a }}$ unit is $\mathrm{kW} / \mathrm{kg}$.

\section{Color Analysis}

Colour is the primary criterion when determining product quality and consumer choice. The lightness or darkness are presented with $L^{*}$ values in Hunter colour system. Also, the positive $a^{*}$ values represent redness 
and the negative ones represent greenness as the positive $b^{*}$ values represent yellowness and the negative ones represents blueness. Before and after the all three drying processes, colour parameters were measured by using a handheld colorimeter. (PCE-CSM 1; PCE Instruments UK Ltd., Southampton Hampshire, United Kingdom). More than five measurements were performed for each squid sample. Also total color changes $(\Delta E)$ is calculated from the following equation (11):

$$
\Delta E=\sqrt{\left(\left(L_{o}-L\right)^{2}+\left(a_{0}-a\right)^{2}+\left(b_{0}-b\right)^{2}\right)}
$$

\section{Results and Discussion}

\section{Drying Curves}

The effect of drying temperature and different drying methods on the squid drying is shown in Fig. 2. The initial average moisture content of squids for infrared drying without pre-treatment was $3.87 \mathrm{~kg}$ water / kg dry matter, and with ultrasound pretreatment was $7.197 \mathrm{~kg}$ water / kg dry matter. The dried squids were decreased to $0.0922 \pm 0.0156 \mathrm{~kg}$ water $/ \mathrm{kg}$ dry matter and $0.3337 \pm 0.0865 \mathrm{~kg}$ water / kg dry matter for infrared drying without pre- treatment and with pre-
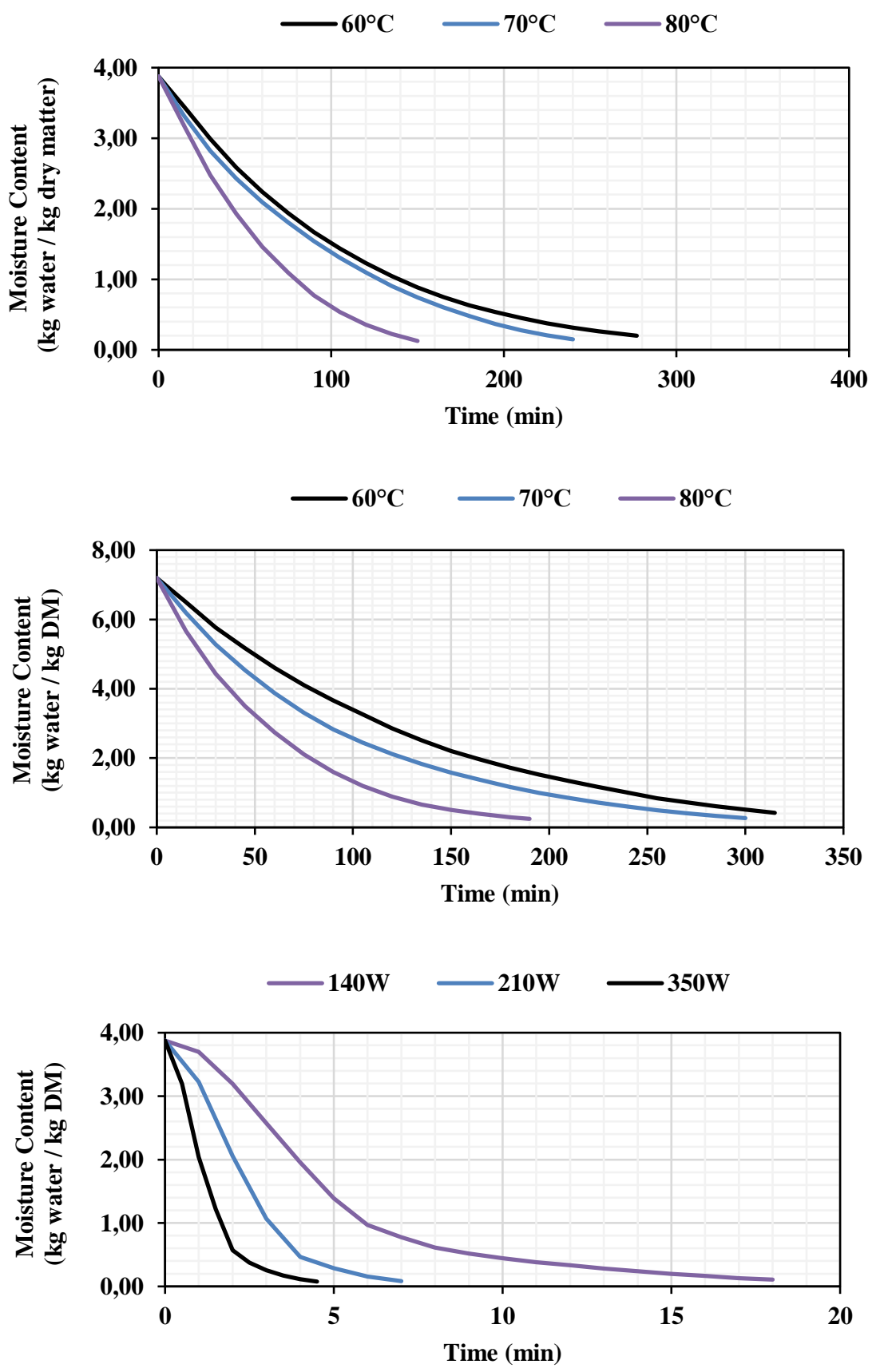

Figure 2. Drying curves of Loligo vulgaris dried by: a. IR, b. US-IR and c. MW. 
treatment, respectively. The initial average moisture content of squids for microwave oven drying was 3.87 $\mathrm{kg}$ water / kg dry matter, and the dried squids were decreased to $0.1628 \pm 0.0372 \mathrm{~kg}$ water $/ \mathrm{kg}$ dry matter. From the curves, it is seen that the increase in temperature and power level decreased the drying times. In the infrared drying, times were found as 277 , 240 and $150 \mathrm{~min}$ for the temperatures of 60, 70 and $80^{\circ} \mathrm{C}$, respectively. In the infrared drying with ultrasound pretreatment times were found as 315,300 and $190 \mathrm{~min}$ for the temperatures of 60,70 and $80^{\circ} \mathrm{C}$, respectively. Furthermore, in the microwave oven drying times were found as 18, 7 and $4.5 \mathrm{~min}$ for the power levels of 140, 210 and $350 \mathrm{~W}$, respectively. The drying times for squid found higher than infrared drying (Kipcak et al., 2019) and the microwave method of mussel (Kipcak, 2017) which is another common seafood as expected. The obtained results are consistent with results of other meat drying studies (Aksoy et al., 2019; Başlar et al., 2014: Kipcak \& İsmail, 2020; Mohd Rozainee et al., 2010).

The falling-rate period is usually where the drying takes place (Sarpong et al., 2019). In Fig. 3 the drying rate plot of the squid dried with different methods with respect to the moisture content is given. It can be seen from the plots that only the falling-rate period is detectable in the figure and the drying rates increase as the drying temperature and power level increase as given in the literature (Kipcak, 2017; Kipcak et al., 2018; Kipcak \& İsmail, 2020).
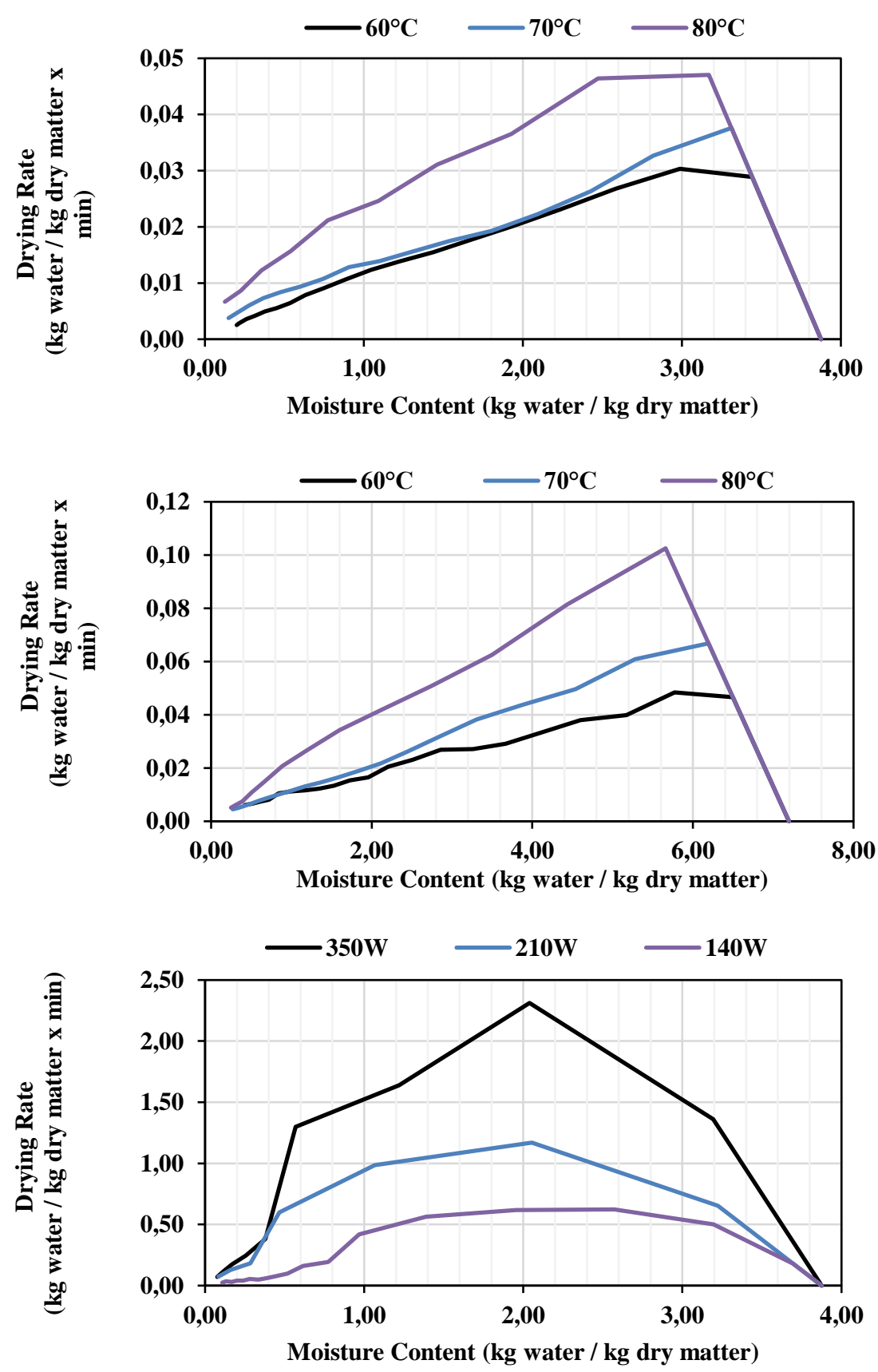

Figure 3. Drying rate curves of Loligo vulgaris dried by: a. IR, b. US-IR and c. MW. 
In infrared drying falling-rate period is found between $2.9874-0.1999,3.3111-0.1487$ and 3.1696 $0.1256 \mathrm{~kg}$ water / kg dry matter for the temperatures of 60,70 and $80^{\circ} \mathrm{C}$, respectively. In infrared drying with ultrasound pretreatment rising-rate period is calculated between $5.7703-0.4202,6.1935-0.2681$ and 5.6579 $0.2472 \mathrm{~kg}$ water / kg dry matter for the temperatures of 60,70 and $80^{\circ} \mathrm{C}$, respectively. Moreover, in microwave oven falling-rate period is obtained between 3.1963 $0.1077,2.0532-0.0838$ and $2.0384-0.0766 \mathrm{~kg}$ water / $\mathrm{kg}$ dry matter for the power levels of 140, 210 and 350 W, respectively. As in the microwave (Kipcak, 2017) and infrared drying (Kipcak et al., 2019) studies given in the literature, the constant-rate period is not obtained.

In all three drying methods, drying took place majorly in the period of falling-rate. In many meat-type products drying study the falling-rate is stated as a main drying phase. As the resistance of the water increases due to the decrease of porosity owing to the shrinkage of the sample, the drying rate decreases (Doymaz et al., 2015b; Kipcak, 2017).

\section{Modelling and Regression Analyses Results}

The experimental data were fitted to aforementioned models and the model parameters and statistical data are represented in Table 1 . The best model was selected by evaluating the coefficient of determination $\left(R^{2}\right)$, reduced chi-square error $\left(\chi^{2}\right)$ and root mean square error (RMSE). For all the drying techniques average $R^{2}$ values below 0.9996 for IR and US-IR methods and 0.996 for MW method were not listed.
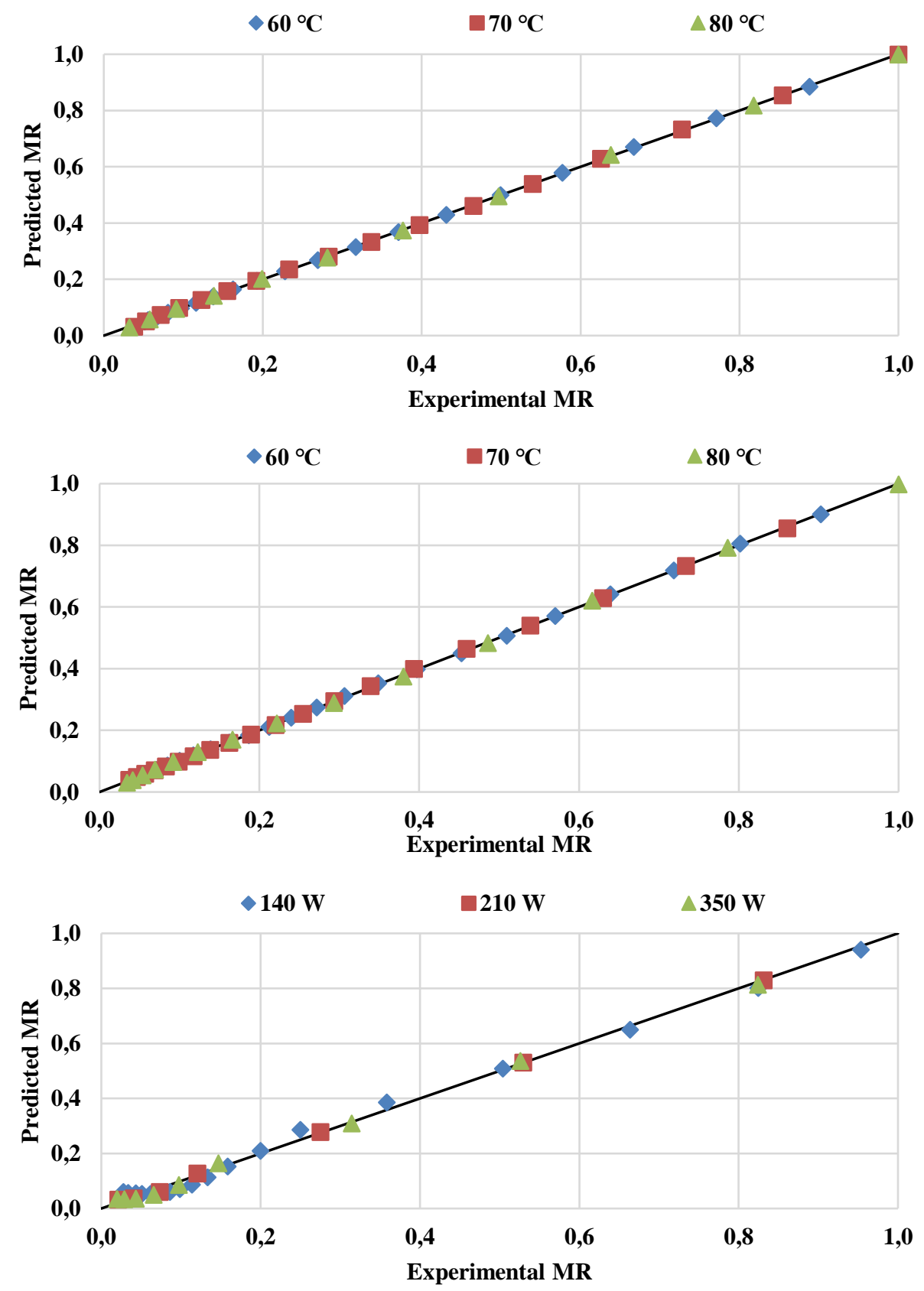

Figure 4. Comparison of the experimental and predicted MR values obtained from Midilli \& Kucuk model: a. IR, b. US-IR and c. MW 
Table 1. IR, US-IR and MW methods coefficients and statistical data (Avg. $\mathrm{R}^{2}>0.9996$ )

\begin{tabular}{|c|c|c|c|c|c|}
\hline Method & Model & Parameter & $60^{\circ} \mathrm{C}$ & $70^{\circ} \mathrm{C}$ & $80^{\circ} \mathrm{C}$ \\
\hline \multirow{5}{*}{ IR } & \multirow{5}{*}{ Aghbashlo et al. } & $\mathrm{k}_{1}$ & 0.008715 & 0.009529 & 0.013601 \\
\hline & & $k_{2}$ & -0.000725 & -0.000995 & -0.002658 \\
\hline & & $\mathrm{R}^{2}$ & 0.999864 & 0.999109 & 0.999892 \\
\hline & & $\chi^{2}$ & 0.000012 & 0.000062 & 0.000013 \\
\hline & & RMSE & 0.003230 & 0.007421 & 0.003212 \\
\hline \multirow{7}{*}{ IR } & \multirow{7}{*}{ Midilli \& Kucuk } & a & 1.000821 & 0.998733 & 0.999570 \\
\hline & & k & 0.006705 & 0.010879 & 0.009201 \\
\hline & & $\mathrm{n}$ & 1.073086 & 0.972107 & 1.129560 \\
\hline & & $b$ & -0.000038 & -0.000312 & -0.000279 \\
\hline & & $R^{2}$ & 0.999966 & 0.999852 & 0.999931 \\
\hline & & $\chi^{2}$ & 0.000001 & 0.000007 & 0.000011 \\
\hline & & RMSE & 0.000741 & 0.002372 & 0.002589 \\
\hline \multirow{6}{*}{ IR } & \multirow{6}{*}{ Verma } & $a$ & -1.208400 & -0.021037 & -1.634220 \\
\hline & & k & 0.005410 & -0.004691 & 0.006910 \\
\hline & & g & 0.007020 & 0.009773 & 0.009840 \\
\hline & & $R^{2}$ & 0.999688 & 0.999765 & 0.999353 \\
\hline & & $\chi^{2}$ & 0.000010 & 0.000018 & 0.000086 \\
\hline & & RMSE & 0.002844 & 0.003841 & 0.007911 \\
\hline \multirow{5}{*}{ US-IR } & \multirow{5}{*}{ Aghbashlo et al. } & $\mathrm{k}_{1}$ & 0.007126 & 0.010203 & 0.015546 \\
\hline & & $\mathrm{k}_{2}$ & -0.000587 & -0.000040 & -0.000786 \\
\hline & & $R^{2}$ & 0.999888 & 0.999791 & 0.999891 \\
\hline & & $\chi^{2}$ & 0.000007 & 0.000009 & 0.000009 \\
\hline & & RMSE & 0.002573 & 0.002927 & 0.002777 \\
\hline \multirow{7}{*}{ US-IR } & \multirow{7}{*}{ Midilli \& Kucuk } & $\mathrm{a}$ & 1.000765 & 1.003365 & 0.997526 \\
\hline & & k & 0.006437 & 0.011412 & 0.013829 \\
\hline & & $\mathrm{n}$ & 1.030274 & 0.973684 & 1.038813 \\
\hline & & $b$ & -0.000098 & -0.000044 & -0.000052 \\
\hline & & $R^{2}$ & 0.999942 & 0.999894 & 0.999805 \\
\hline & & $\chi^{2}$ & 0.000003 & 0.000007 & 0.000021 \\
\hline & & RMSE & 0.001435 & 0.002374 & 0.003849 \\
\hline \multirow{5}{*}{ US-IR } & \multirow{5}{*}{ Page } & k & 0.005278 & 0.010198 & 0.013128 \\
\hline & & $\mathrm{n}$ & 1.080753 & 1.001241 & 1.055468 \\
\hline & & $R^{2}$ & 0.999579 & 0.999785 & 0.999713 \\
\hline & & $\chi^{2}$ & 0.000024 & 0.000004 & 0.000028 \\
\hline & & RMSE & 0.004688 & 0.001820 & 0.004927 \\
\hline \multirow{6}{*}{ US-IR } & \multirow{6}{*}{ Verma } & a & -0.472334 & 0.134801 & -1.561660 \\
\hline & & $\mathrm{k}$ & 0.003449 & 0.010258 & 0.024460 \\
\hline & & $\mathrm{g}$ & 0.006059 & 0.010258 & 0.020830 \\
\hline & & $\mathrm{R}^{2}$ & 0.999913 & 0.999784 & 0.999838 \\
\hline & & $\chi^{2}$ & 0.000003 & 0.000004 & 0.000018 \\
\hline & & RMSE & 0.001672 & 0.001778 & 0.003746 \\
\hline \multirow{5}{*}{ US-IR } & & $a$ & 128.0316 & 97.50345 & 60.65976 \\
\hline & & b & 1.080800 & 1.001240 & 1.055470 \\
\hline & Weibull & $R^{2}$ & 0.999579 & 0.999785 & 0.999713 \\
\hline & & $\chi^{2}$ & 0.000024 & 0.000004 & 0.000028 \\
\hline & & RMSE & 0.004688 & 0.001820 & 0.004927 \\
\hline Method & Model & Parameter & $140 \mathrm{~W}$ & $210 W$ & $350 W$ \\
\hline & & $a$ & 0.423361 & 2.765300 & 0.428485 \\
\hline & & k & 0.322655 & 0.789800 & 1.356527 \\
\hline & & $b$ & 0.295154 & 0.625750 & 0.694441 \\
\hline MW & Jena \& Das & c & 0.860162 & -1.019080 & 0.847159 \\
\hline & & $\mathrm{R}^{2}$ & 0.994154 & 0.998028 & 0.998636 \\
\hline & & $\chi^{2}$ & 0.000753 & 0.000505 & 0.000262 \\
\hline & & RMSE & 0.024384 & 0.015884 & 0.012539 \\
\hline & & $\mathrm{a}$ & 1.023327 & 1.001463 & 1.004989 \\
\hline & & k & 0.088076 & 0.193728 & 0.643453 \\
\hline & & $\mathrm{n}$ & 1.522713 & 1.753099 & 1.566868 \\
\hline MW & Midilli \& Kucuk & $b$ & 0.003247 & 0.004120 & 0.007282 \\
\hline & & $\mathrm{R}^{2}$ & 0.995760 & 0.999619 & 0.998900 \\
\hline & & $x^{2}$ & 0.000283 & 0.000097 & 0.000211 \\
\hline & & RMSE & 0.014936 & 0.006981 & 0.011262 \\
\hline
\end{tabular}


The model that fits best the experimental data for all the drying methods of microwave oven, infrared drying and infrared drying with ultrasound pretreatment was found as Midilli \& Kucuk model in Table 1. $R^{2}$ values are obtained between. 0.999966 0.999852, 0.999942-0.999805 and $0.999619-0.995760$ for infrared drying, infrared drying with ultrasound pretreatment and microwave oven, respectively. $\chi^{2}$ values are found between, $0.000001-0.000011$, $0.000021-0.000003$ and $0.000283-0.000097$ for infrared drying, infrared drying with ultrasound pretreatment and microwave oven, respectively. RMSE values are calculated between $0.002589-0.000741$, $0.003849-0.001435$ and $0.014936-0.006981$ for infrared drying, infrared drying with ultrasound pretreatment and microwave oven, respectively. The best model for the study of mussel in the infrared drying (Kipcak et al., 2019) was also found as Midilli \& Kucuk with the $R^{2}$ values between 0.999150 - 0.999750 . Moreover, the best model was found as Weibull (Kipcak, 2017) with the $R^{2}$ values between 0.998135 - 0.999929 for the microwave drying.

The predicted MR values against experimental MR values were plotted in Fig. 4 for Midilli \& Kucuk model. As the plot of the predicted versus experimental data gives match as a nearly straight line it can be said that the data in good agreement.

\section{Effective Moisture Diffusivity Values}

From the slope of the $\ln (M R)$ versus drying time (s) plot, $D_{\text {eff }}$ values are calculated. For infrared drying $D_{\text {eff }}$ values are found as $6.57 \times 10^{-10}, 7.95 \times 10^{-10}$ and, $1.35 \mathrm{x}$ $10^{-9} \mathrm{~m}^{2} / \mathrm{s}$ for the temperatures of 60,70 and $80^{\circ} \mathrm{C}$, respectively. For infrared drying with ultrasound pretreatment $D_{\text {eff }}$ values are found as $5.11 \times 10^{-10}, 6.46 \mathrm{x}$ $10^{-10}$ and $1.09 \times 10^{-9} \mathrm{~m}^{2} / \mathrm{s}$ for the temperatures of 60,70 and $80^{\circ} \mathrm{C}$, respectively. For microwave oven $D_{\text {eff }}$ values are found as $1.25 \times 10^{-8}, 3.52 \times 10^{-8}$ and, $5.62 \times 10^{-8} \mathrm{~m}^{2} / \mathrm{s}$ for the temperatures of 140, 210 and $350 \mathrm{~W}$, respectively. The obtained $D_{\text {eff }}$ values shows the microwave oven had the highest diffusion coefficient values then infrared dryer follows and infrared drying with ultrasound pretreatment has the lowest diffusion coefficient values. For the biological materials, diffusion coefficient values are within the general range of $10^{-8}$ to $10^{-12} \mathrm{~m}^{2} / \mathrm{s}$ (Zogzas et al., 1996). Thus, the calculated $D_{\text {eff }}$ values were mutually compatible with the literature. The increase in the temperature and power level causes a temperature increase of the meat-type of products, which increases the vapour pressure (Sa-adchom et al., 2011; Akhtar and Omre, 2018). The temperature effect on the $D_{\text {eff }}$ values can be calculated by using the equations between (12-14):

$$
\begin{aligned}
& I R \rightarrow D_{\text {eff }}=3 \times 10^{-10}+2 \times 10^{-10}\left(R^{2}=0.8922\right) \\
& I R-U S \rightarrow D_{\text {eff }}=3 \times 10^{-10}+2 \times 10^{-10}\left(R^{2}=0.8922\right)
\end{aligned}
$$

$\mathrm{MW} \rightarrow \mathrm{D}_{\text {eff }}=2 \times 10^{-08}+9 \times 10^{-09}\left(\mathrm{R}^{2}=0.9995\right)$

As the drying rates are smaller, the calculated $D_{\text {eff }}$ values are lower than the microwave and infrared drying $D_{\text {eff }}$ values calculated for mussels (Kipcak, 2017; Kipcak et al., 2019).

\section{Activation Energy Values}

From the slope of the plot of $\ln \left(D_{\text {eff }}\right)$ vs. $1 / T(1 / K)$ and $\ln \left(D_{\text {eff }}\right)$ vs. $\mathrm{m} / \mathrm{P}, E_{a}$ values are calculated. The estimated values $E_{a}$ are 35.2 and $37.124 \mathrm{~kJ} / \mathrm{mol}$ for infrared drying and infrared drying with ultrasound pretreatment, and $35.434 \mathrm{~kW} / \mathrm{kg}$ for microwave oven. It can be seen the activation energy values for infrared drying with pre-treatment and without pre-treatment lie within $12.7-110 \mathrm{~kJ} / \mathrm{mol}$ general range for food materials (Zogzas et al., 1996).

\section{Color Results}

Colour parameters $L^{*}, a^{*}$ and $b^{*}$ of dried squids by different methods with the $\Delta \mathrm{E}$ values are shown in Table 2. When drying methods were compared, the highest " $L$ " values were seen in the microwave oven. Since the " $L$ " value represents lightness (100) and darkness (0), higher " $L$ " values are obtained as expected in the microwave oven due to less drying times compared to other methods.

Besides that, the lowest " $\mathrm{L}^{* \text { " }}$ values were obtained in the infrared dryer due to the highest drying times. As the drying time of infrared drying with ultrasound pretreatment is between the microwave oven and infrared drying times, its " $L^{*}$ " values are also between the " $L$ *" values of these methods. Redness values "a*" were obtained from the highest to the lowest in infrared dryer, infrared drying with ultrasound pre-treatment and microwave oven, respectively. Furthermore, the yellowness values " $b$ *" were obtained in microwave oven, infrared drying with ultrasound pre-treatment and infrared drying without a pre-treatment, from the highest to the lowest respectively. Drying time, temperature and power levels often lead to color changes. The highest $\Delta \mathrm{E}$ values obtained at the $\mathrm{MW}$ method due to the highest changes in " $\mathrm{L}^{*}$ " and " $\mathrm{b}$ *" values and the lowest $\Delta \mathrm{E}$ values obtained at the method of US-IR. At all drying methods " $L$ " " and " $b$ *" values are increased with increasing temperature or power and "a*" values are decreased; as also seen in the literature (Isik et al., 2019; Aksoy et al., 2019).

\section{Conclusion}

In this study, infrared, ultrasonic pre-treated infrared and microwave drying curves and kinetics of Loligo vulgaris were studied with the drying temperatures of 60,70 and $80^{\circ} \mathrm{C}$. In all of the methods Midilli \& Kucuk model best fits the drying data with very high $\mathrm{R}^{2}$, and very low $\chi^{2}$ and RMSE values. Mainly falling- 
Table 2. Color values of Loligo vulgaris dried by the methods of IR, US-IR and MW

\begin{tabular}{|c|c|c|c|c|}
\hline Samples & $L^{*}$ & $a^{*}$ & $b^{*}$ & $\Delta \mathrm{E}$ \\
\hline Fresh & $59.33 \pm 0.42$ & $-6.06 \pm 0.11$ & $-8.37 \pm 0.35$ & - \\
\hline \multicolumn{5}{|c|}{ IR Method } \\
\hline Temperature $\left({ }^{\circ} \mathrm{C}\right)$ & $L^{*}$ & $a^{*}$ & $b^{*}$ & $\Delta \mathrm{E}$ \\
\hline 60 & $37.28 \pm 0.43$ & $13.40 \pm 0.15$ & $18.99 \pm 0.27$ & $33.82 \pm 0.12$ \\
\hline 70 & $38.84 \pm 0.44$ & $12.27 \pm 0.13$ & $19.50 \pm 0.29$ & $33.45 \pm 0.11$ \\
\hline 80 & $42.25 \pm 0.46$ & $10.93 \pm 0.10$ & $20.18 \pm 0.31$ & $33.23 \pm 0.08$ \\
\hline \multicolumn{5}{|c|}{ US-IR Method } \\
\hline Temperature $\left({ }^{\circ} \mathrm{C}\right)$ & $\mathrm{L}^{*}$ & $a^{*}$ & $b^{*}$ & $\Delta \mathrm{E}$ \\
\hline 60 & $39.85 \pm 0.43$ & $13.08 \pm 0.14$ & $24.94 \pm 0.34$ & $38.44 \pm 0.14$ \\
\hline 70 & $41.08 \pm 0.45$ & $11.22 \pm 0.13$ & $26.42 \pm 0.35$ & $38.84 \pm 0.12$ \\
\hline 80 & $43.50 \pm 0.48$ & $10.61 \pm 0.09$ & $28.13 \pm 0.38$ & $40.18 \pm 0.11$ \\
\hline \multicolumn{5}{|c|}{ MW Method } \\
\hline Temperature $\left({ }^{\circ} \mathrm{C}\right)$ & $\mathrm{L}^{*}$ & $a^{*}$ & $b^{*}$ & $\Delta \mathrm{E}$ \\
\hline 60 & $75.20 \pm 0.99$ & $11.89 \pm 0.12$ & $40.21 \pm 0.59$ & $61.88 \pm 0.30$ \\
\hline 70 & $77.38 \pm 1.02$ & $11.15 \pm 0.11$ & $42.47 \pm 0.63$ & $64.67 \pm 0.35$ \\
\hline 80 & $79.05 \pm 1.05$ & $10.40 \pm 0.10$ & $45.30 \pm 0.68$ & $67.63 \pm 0.40$ \\
\hline
\end{tabular}

rate period was obtained in the drying of Loligo vulgaris at each method. The highest $D_{\text {eff }}$ and $E_{a}$ values were obtained in the method of microwave method and ultrasonic pre-treatment decreased the $D_{\text {eff }}$ and $E_{a}$ values due to the swelling of water during the pretreatment. For the comparison between the methods, MW is obviously the best method for the lowest drying times, which will led to more energy saving. On the other hand, for the color changes the best method is the IR method due to the lowest total color changes. For the future studies may be other pretreatment methods could be used before the drying experiments and may be the drying experiments conducted after cooking the squid samples.

\section{Acknowledgements}

The authors received no financial support for the research, authorship, and/or publication of this article.

\section{Conflict of Interest} interest.

The authors declare that they have no conflict of

\section{References}

Abdelmalek, B. E., Gómez-Estaca, J., Sila, A., Martinez-Alvarez, O., Gómez-Guillén, M.C., Chaabouni-Ellouz, S., Ayadi, M. A., Bougatef, A. (2016). Characteristics and functional properties of gelatin extracted from squid (Loligo vulgaris) skin. LWT - Food Science and Technology, 65, 924-931. https://doi.org/10.1016/j.lwt.2015.09.024

Adak, N., Heybeli, N., Ertekin, C. (2016). Infrared drying of strawberry. Food Chemistry, 219. 10.1016. https://doi.org/10.1016/j.foodchem.2016.09.103

Ahmat, T., Barka, M., Aregba, A. W., Bruneau, D. (2015). Convective drying kinetics of fresh beef: an experimental and modeling approach. Journal of Food Processing and Preservation, 39(6), 2581-2595.

https://doi.org/10.1111/jfpp.12508
Akhtar, J., More, P. K. (2018). Influence of temperatures and pretreatments on chicken meat during convective drying. International Journal of Chemical Studies, 6(1), 1590-1597.

Aksoy, A., Karasu, S., Akcicek, A., Kayacan, S. (2019). Effects of different drying methods on drying kinetics, microstructure, color, and the rehydration ratio of minced meat. Foods. 8(6), E216. https://doi.org/10.3390/foods8060216

Ayanwale, B. A., Ocheme, O. B., Oloyede, O. O. (2007). The effect of sun-drying and oven-drying on the nutritive value of meat pieces in hot humid environment. Pakistan Journal of Nutrition, 6, 370-374. https://doi.org/10.3923/pjn.2007.370.374

Başlar, M., Kılıçlı, M., Toker, O. S., Sağdıç, O., Arici, M. (2014). Ultrasonic vacuum drying technique as a novel process for shortening the drying period for beef and chicken meats. Innovative Food Science and Emerging Technologies, 26, 182-190. https://doi.org/10.1016/j.ifset.2014.06.008

Doymaz, i. (2010). Evaluation of Mathematical Models for Prediction of Thin-Layer Drying of Banana Slices. International Journal of Food Properties, 13(3), 486-497. https://doi.org/10.1080/10942910802650424

Doymaz, I., Özdemir, Ö. (2014). Effect of air temperature, slice thickness and pretreatment on drying and rehydration of tomato. International Journal of Food Science \& Technology, 49, 558-564. https://doi.org/10.1111/ijfs.12337

Doymaz, I., Kipcak, A. S., Piskin, S. (2015). Characteristics of thin-layer infrared drying of green bean. Czech Journal of Food Sciences, 33(1), 83-90. https://doi.org/10.17221/423/2014-CJFS

Doymaz, I., Kipcak, A. S., Piskin, S. (2015). Microwave drying of green bean (Phaseolus vulgaris) slices: drying kinetics and physical quality. Czech Journal of Food Sciences 33(4), 367-376. https://doi.org/10.17221/566/2014CJFS

Duan, X., Zhang, M., Li, X., Mujumdar, A. (2008). Ultrasonically Enhanced Osmotic Pretreatment of Sea Cucumber Prior to Microwave Freeze Drying. Drying Technology, 26, 420-426. https://doi.org/10.1080/07373930801929201

FAO (2017). Food and Agriculture Organization of the United Nations Fishery and Aquaculture Department. 
Fernandes, F., Gallao, M., Rodrigues, S. (2008). Effect of osmotic dehydration and ultrasound pre-treatment on cell structure: Melon dehydration. LWT - Food Science and Technology, 41, 604-610. 10.1016. https://doi.org/10.1016/j.lwt.2007.05.007

Fernandes, F. A. N., Braga1, T. R., Silva, E. O., Rodrigues, S. (2019). Use of ultrasound for dehydration of mangoes (Mangifera indicaL.): kinetic modeling of ultrasoundassisted osmotic dehydrationand convective air-drying. Journal of Food Science and Technology, 56(4), 17931800. https://doi.org/10.1007/s13197-019-03622-y

Garcia-Noguera, J., Oliveira, F., Gallao, M., Weller, C., Rodrigues, S., Fernandes, F. (2010). Ultrasound Assisted Osmotic Dehydration of Strawberries: Effect of Pretreatment Time and Ultrasonic Frequency. Drying Technology, 28, 294-303. 10.1080. https://doi.org/10.1080/07373930903530402

Hii, C. L., Itam, C. E., Ong, S. P. (2014). Convective air drying of raw and cooked chicken meats. Drying Technology 32, 1304-1309.

https://doi.org/10.1080/07373937.2014.924133

Isik, A., Ozdemir, M., Doymaz, I. (2019). Effect of hot air drying on quality characteristics and physicochemical properties of bee pollen. Food Science and Technology (Campinas), 39, 224-231. https://doi.org/10.1590/fst.02818

Jereb, P., Allcock, L. A., Lefkaditou, E., Piatkowski, U., Hastie, L. C., Pierce, G. J. (2015). Cephalopod biology and fisheries in Europe: II. Species Accounts. ICES. https://doi.org/10.13140/RG.2.1.1081.6164

Kipcak, A. S. (2017). Microwave drying kinetics of mussels (Mytilus edulis). Research on Chemical Intermediates, 43(3), 1429-1445. https://doi.org/10.1007/s11164-0162707-4

Kipcak, A. S., Doymaz, İ., Derun, E. M. (2019). Infared drying kinetics of blue mussels and physical properties. Chemical Industry \& Chemical Engineering Quarterly, 25(1), 1-10. https://doi.org/10.2298/CICEQ170808014K

Kipcak A. S., Ismail, O. (2018). Comparison of the microwave drying kinetics of culture and natural asparagus. Acta Scientiarum Technology, 40, e39922. https://doi.org/10.4025/actascitechnol.v40i1.39922

Kipcak A. S., Ismail, O. (2020). Microwave drying of fish, chicken and beef samples. Journal of Food Science and Technology. https://doi.org/10.1007/s13197-02004540-0

La Fuente, C., Tadini, C. (2017). Unripe Banana Flour Produced by Air-Drying Assisted with Ultrasound - Description of the Mechanisms Involved to Enhance the Mass Transfer in Two Approaches. International Journal of Food Engineering, 13, 10.1515. https://doi.org/10.1515/ijfe2017-0178

Liu, S., Zhu, W., Bai, X., You, T., Yan, J. (2018). Effect of ultrasonic energy density on moisture transfer during ultrasound enhanced vacuum drying of honey. Journal of Food Measurement and Characterization, 13(4), 559570. https://doi.org/10.1007/s11694-018-9969-z

Mewa, E. A., Okoth, M. W., Kunyanga, C. N., Rugiri, M. N. (2019). Experimental Evaluation of Beef Drying Kinetics in a Solar Tunnel Dryer. Renewable Energy, 139, 235241. https://doi.org/10.1016/j.renene.2019.02.067

Mohd Rozainee, T., Ng, P. S. (2010). Microwave assisted hot air convective dehydration of fish slice: drying characteristics, energy aspects and colour assessment World Engineering Congress 2010 - Conference on Advanced Processes and Materials, pp 41-46, Sarawak, Malaysia, 2-5 August.

https://doi.org/10.18517/ijaseit.1.1.11

Namsanguan, Y., Tia, W., Devahastin, S., Soponronnarit, S. (2004). Drying Kinetics and Quality of Shrimp Undergoing Different Two-Stage Drying Processes. Drying Technology, 22(4), 759-778. https://doi.org/10.1081/DRT-120034261

Nowacka, M., Wiktor, A., Śledź, M., Jurek, N., \& WitrowaRajchert, D. (2012). Drying of ultrasound pretreated apple and its selected physical properties. Journal of Food Engineering, 113(3), 427-433. https://doi.org/10.1016/j.jfoodeng.2012.06.013

Osman, I. (2017). An experimental and modeling investigation on drying of chicken meat in convective dryer. Studia Universitatis Babeș-Bolyai Chemia, 62, 459-469. 10.24193 https://doi.org/10.24193/subbchem.2017.4.39

Purnomo Sidh, S., Pujiant Andreas., Prasety D., Nurfauzi A, Muhfiza (2018). Experimental Study of Salted Fish Drying Under Greenhouse Dryer. Russian Journal of Agricultural and Socio-Economic Sciences. 77, 281-287. 10.18551. https://doi.org/10.18551/rjoas.2018-05.33

Rodrigues, S., Fernandes, F. A. N. (2007). Use of Ultrasound as Pretreatment for Dehydration of Melons. Drying Technology, 25(10), 1791-1796. https://doi.org/10.1080/07373930701595409

Romero, C., Yépez, v. B. (2014). Ultrasound as pretreatment to convective drying of Andean blackberry (Rubus glaucus Benth). Ultrasonics sonochemistry, 22, 10.1016. https://doi.org/10.1016/j.ultsonch.2014.06.011

Sa-adchom, P., Swasdisevi, T., Nathakaranakule, A., Soponronnarit, S. (2011). Drying kinetics using superheated steam and quality attributes of dried pork slices for different thickness, seasoning and fibers distribution. Journal of Food Engineering, 104, 105-113. https://doi.org/10.1016/j.jfoodeng.2010.12.002

Sarpong, F., Zho, C., Bai, J., Amenorfe, L. P., Golly, M. K., Ma, H. (2019). Modeling of Drying and Ameliorative Effects of Relative Humidity $(\mathrm{RH})$ against B-carotene Degradation and Color of Carrot (Daucus carota var) Slices. Food Science and Biotechnology, 28, 75-85. https://doi.org/10.1007/s10068-018-0457-3

Sevim, S., Derun, E. M., Tugrul, N., Doymaz, I., Kipcak, A. S. (2019). Temperature controlled infrared drying kinetics of mussels. Journal of Indian Chemical Society, 96, 12331238.

Vega-Gálvez, A., Miranda, M., Clavería, R., Quispe, I., Vergara, J., Uribe, E., Di Scala, K. (2011). Effect of air temperature on drying kinetics and quality characteristics of osmotreated jumbo squid (Dosidicus gigas). LWT - Food Science and Technology, 44(1), 16-23. https://doi.org/10.1016/j.Iwt.2010.06.012

Zhengbin, H., Zijian, Z., Fei, Y., Songlin, Y. (2014). Effect of Ultrasound Pretreatment on Wood Prior to Vacuum Drying. Ciencia y Tecnología 16(4), 395 - 402. https://doi.org/10.4067/S0718-221X2014005000031

Zogzas, N. P., Maroulis, Z. B., Marinos-Kouris, D. (1996). Moisture diffusivity data compilation in foodstuffs. Drying Technology, 14, 2225-2253. https://doi.org/10.1080/07373939608917205 